\title{
Evaluation of erosion characteristics of soils using the pinhole test
}

\author{
Ba Huu Dinh', Anh-Dan Nguyen', Seo-Yong Jang² and Young-Sang Kim ${ }^{3^{*}}$
}

\section{${ }^{*}$ Correspondence:}

geoyskim@jnu.ac.kr

${ }^{3}$ Department of Civil

Engineering, Chonnam

National University,

Yongbong-ro 77, Buk-gu,

Gwangju 61186, South Korea

Full list of author information

is available at the end of the

article

\begin{abstract}
This paper investigates the erosion characteristics of soils using the pinhole test. The tests were conducted with two undisturbed clay samples and five disturbed sandy soil samples. Based on the pinhole test results, a process to analyze the critical shear stress and erosion rate was proposed. The result indicates that the particle size distribution and coefficient of uniformity of soils are significant factors that affect the erosion characteristics of the soil. Samples with a grain size ranging from 0.2 to $0.6 \mathrm{~mm}$ is most susceptible to soil erosion. The erosion coefficients can be used to distinguish between the low erodible soils (ND3 and ND4) and high erodible ones (D1 and D2). Furthermore, it is interesting to note that the critical shear stress might be used as an identification parameter for erosion characteristics of the soil: $\tau_{c}>3.5 \mathrm{~Pa}$ (ND3), 3.0 $\mathrm{Pa}<\tau_{c}<3.5 \mathrm{~Pa}(\mathrm{D} 2)$, and $\tau_{c}<3.0 \mathrm{~Pa}(\mathrm{D} 1)$.
\end{abstract}

Keywords: Pinhole test, Soil erosion, Uniformity coefficient, Erosion coefficient, Critical shear stress

\section{Introduction}

The erosion of soils caused serious engineering problems of structures (i.e., landslide [17], bank failures [15], ground subsidence [16]) resulting to catastrophic and irreversible failures. Piping failure and rainfall erosion of the embankment are the most typical structural failures caused by soil erosion [13]. In 2005, the piping failure of a metro tunnel constructed in Taiwan was reported (Fig. 1a). They found that the main reason for the failure was the very high dispersive of the silty sand [14]. More recently, in 2018, an earthen and rockfill dam crumbled as a result of heavy summer rain alongside devastating consequences including loss of lives (13 persons) and numerous properties (300 persons homeless) [23].

Another typical failure caused by erosion of the soil is a sinkhole (Fig. 1b). In recent years, many sinkholes have been discovered in Korea; about 70 sinkholes were reported between January 2012 and July 2014. Most of them were caused by the erosion of underground soils owing to the ruptured sewer pipes and heavy rainfall [12]. The most important factor among the common causes of these problems is the erosion characteristic of soils, but so far, most designs and constructions have not considered this part much in Korea. 


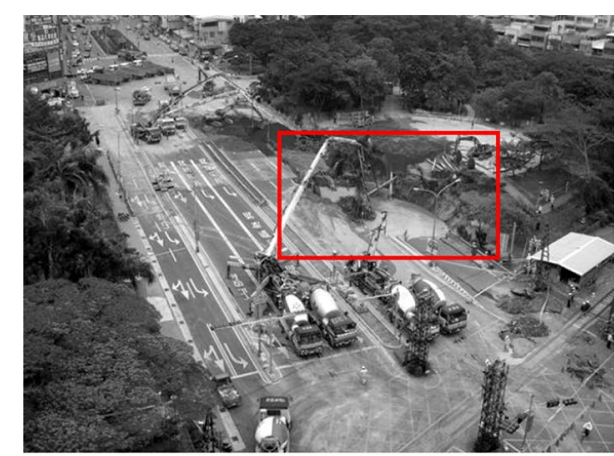

a

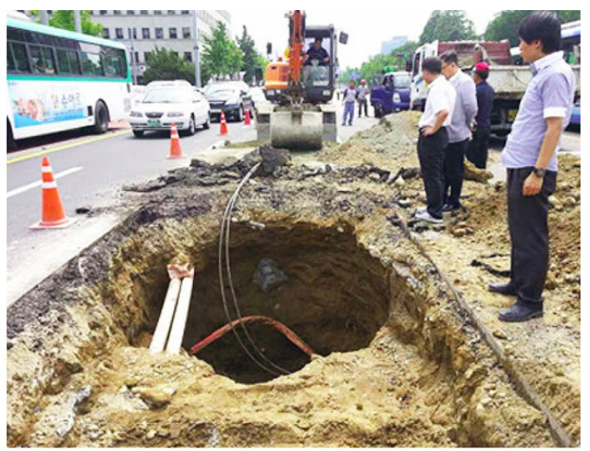

b

Fig. 1 a The cave-in in Kaohsiung, Taiwan b a sinkhole found in Seoul, South Korea

To evaluate the erodibility of soils, many studies were conducted with different devices and testing methods: crumb test [8], jet erosion test [7, 10, 19], flow pump tests, and flume erosion tests $[1,18]$, pinhole test [2, 20, 21], hole erosion test [24].

Among these tests, the pinhole test is well-known as the most reliable for classification and identification of the erodibility of the soil since it directly measures the erodibility and dispersibility of the soil caused by the water flow in a small hole in the center of the soil sample $[13,21]$. The advantage of this test is the small sample required, easy sample preparation, and testing procedure. According to ASTM (2006), a pinhole test is used to identify and classify the erodibility of the soil based on the flow rate of discharge water, cloudiness, the size of the hole, and the applied pressure. There are 6 levels of the dispersive ranging from very high dispersive soils to non-dispersive soils (D1, D2, ND4, ND3, ND2, ND1) [2].

This study investigates the erodibility of different soil types (clay, SM soil, SP-SM soil) using the pinhole test. The sieve analysis and hydrometer analysis were performed to evaluate the effect of the grain size distribution on the erodibility of the soil. Furthermore, the erosion coefficients and the critical shear stress were calculated as additional parameters for the evaluation of the erodibility of the soils.

\section{Materials}

In this study, soil samples were taken nearby the Nakdong river (Fig. 2). The grain size distribution curves, soil properties, and soil classification parameters are shown in Fig. 3 and Table 1, respectively. Based on the soil classification results, the tested soils are divided into three groups: SP-SM (namely RNB-2 and RNB-3), SM (namely RNB-10, RNB-11, and RNB-13), and undisturbed clay (namely RNB-23).

\section{Experimental program}

Pinhole test apparatus

Figure 4 shows the schematic drawing of the typical pinhole test apparatus. The specimen with the dimension of $32.8 \mathrm{~mm}$ in diameter and $38.0 \mathrm{~mm}$ in height was sandwiched with coarse sand layers at the top and bottom. The wire screen is placed between the specimen and coarse sand to prevent the penetration of the coarse sand into the specimen. A hole $(1.2 \mathrm{~mm}$ in diameter) centered with a truncated cone is 


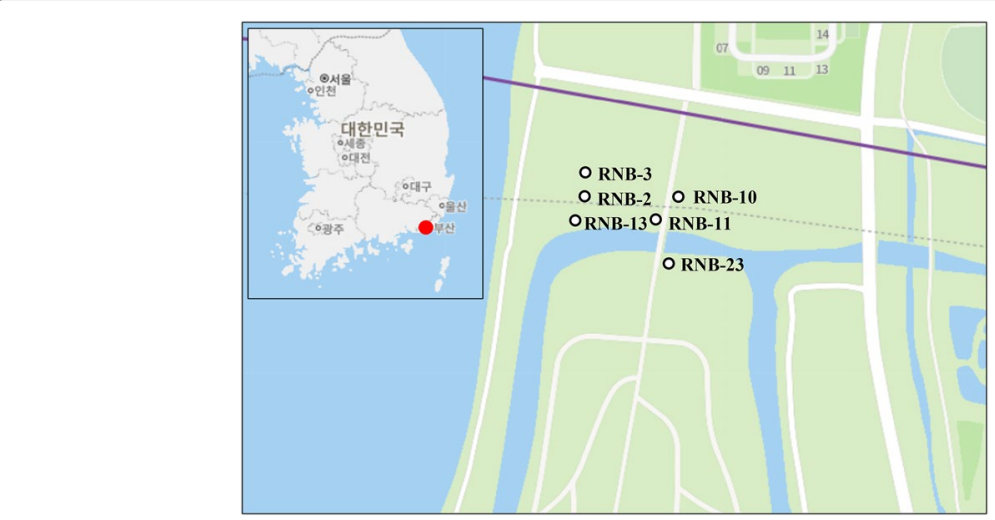

Fig. 2 Soil sampling area

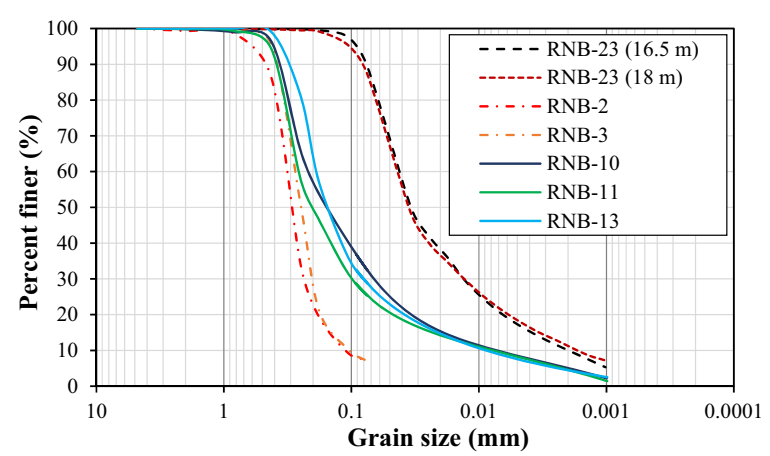

Fig. 3 The grain size distribution of soils

Table 1 Basic soil properties and soil classification parameters

\begin{tabular}{|c|c|c|c|c|c|c|c|c|c|}
\hline \multirow[t]{2}{*}{ Group } & \multirow[t]{2}{*}{ Name } & \multirow[t]{2}{*}{$G_{s}$} & \multirow{2}{*}{$\begin{array}{l}\text { Natural } \\
\text { moisture } \\
\text { content (\%) }\end{array}$} & \multicolumn{6}{|c|}{ Soil classification parameters } \\
\hline & & & & LL & $P l$ & $C_{u}$ & $C_{c}$ & $\begin{array}{l}\text { Percent } \\
\text { passing No.200 } \\
\text { (\%) }\end{array}$ & USCS \\
\hline \multirow[t]{2}{*}{1} & RNB-23 (16.5 m) & 2.69 & 26.9 & 37.5 & 16.6 & 17.0 & 2.52 & 89.4 & $\mathrm{CL}$ \\
\hline & RNB-23 (18 m) & 2.70 & 28.5 & 34.6 & 17.8 & 22.6 & 2.75 & 90.1 & $\mathrm{CL}$ \\
\hline \multirow[t]{2}{*}{2} & RNB-2 & 2.65 & 26.2 & NP & NP & 2.7 & 1.5 & 7.4 & SP-SM \\
\hline & RNB-3 & 2.65 & 22.6 & NP & NP & 2.5 & 1.3 & 7.0 & SP-SM \\
\hline \multirow[t]{3}{*}{3} & RNB-10 & 2.66 & 23.5 & NP & NP & 28.8 & 2.3 & 36.9 & SM \\
\hline & RNB-11 & 2.68 & 23.8 & NP & NP & 30.0 & 4.1 & 25.1 & SM \\
\hline & RNB-13 & 2.67 & 25.3 & NP & NP & 20.0 & 4.0 & 29.8 & SM \\
\hline
\end{tabular}

prefabricated by a No. 19 veterinarian hypodermic needle. At the top plate, the inlet valve is connected to the constant head tank in order to supply distilled water with a $\mathrm{pH}$ of 5.5-7.0. To measure the hydraulic head at the inlet, a pressure transducer with an accuracy of $0.01 \mathrm{kPa}$ is employed. A stopwatch with a reading of $0.1 \mathrm{~s}$ is used to record the erosion time. The volume of outlet water is measured using graduated cylinders with capacities ranging from 10 to $100 \mathrm{~mL}$. 


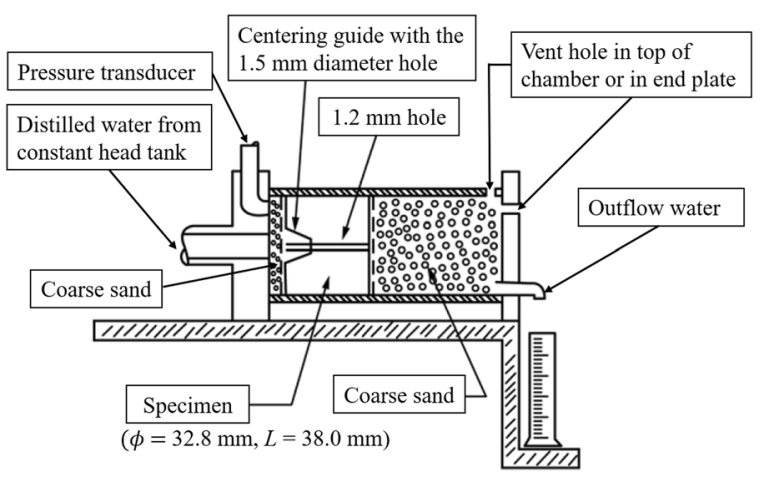

Fig. 4 Schematic diagram of the pinhole test equipment

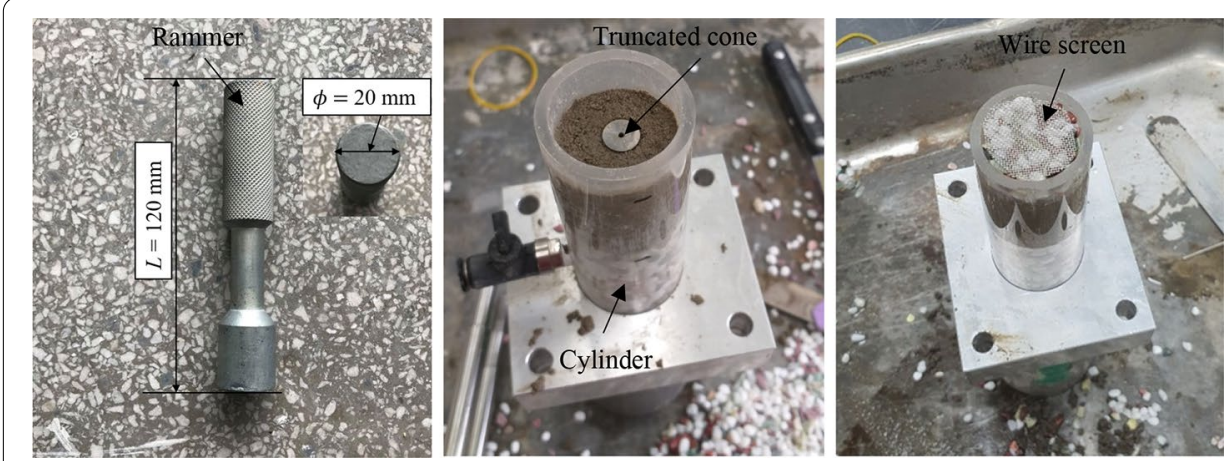

Fig. 5 Preparation of disturbed soil samples

\section{Sample preparation}

Before the commencement of the test, the disturbed soil (RNB-2, RNB-3, RNB-10, RNB-11, RNB-13) was dried with the oven and particles larger than $2 \mathrm{~mm}$ (No. 10 sieves) were removed. Afterward, the three layers of soils were compacted into the pinhole test cylinder until a total length of $38 \mathrm{~mm}$ is reached. It is important to recognize that the specimen should be compacted at natural water content to simulate its in-situ condition. A small rammer (350 g) with a dimension of $20 \mathrm{~mm}$ diameter, $120 \mathrm{~mm}$ length was used to compact the sample (Fig. 5). The samples were divided into three layers and one layer was compacted 20 times at natural water content to simulate its in-situ condition. Note that after compacted 20 times, the density of the compacted sample should be determined and compared with that of in-situ density. If the density of the compacted sample is higher than that of in-situ density, the compacted times are reduced until the difference between these densities lower than $5 \%$ and inverse. The density of the compacted sample can be determined by dividing the mass of the compacted soil by its volume. The mass of the compacted soil is determined by a weight scale while the volume of the soil is $32.09 \mathrm{~cm}^{3}$ (cylinder specimens with a diameter of $3.28 \mathrm{~cm}$ and a length of $3.8 \mathrm{~cm}$ ). The truncated cone centering guide with a $1.5 \mathrm{~mm}$ diameter hole was inserted into the center of the top of the specimen using finger pressure (Fig. 5). The needle was inserted into the centering guide 


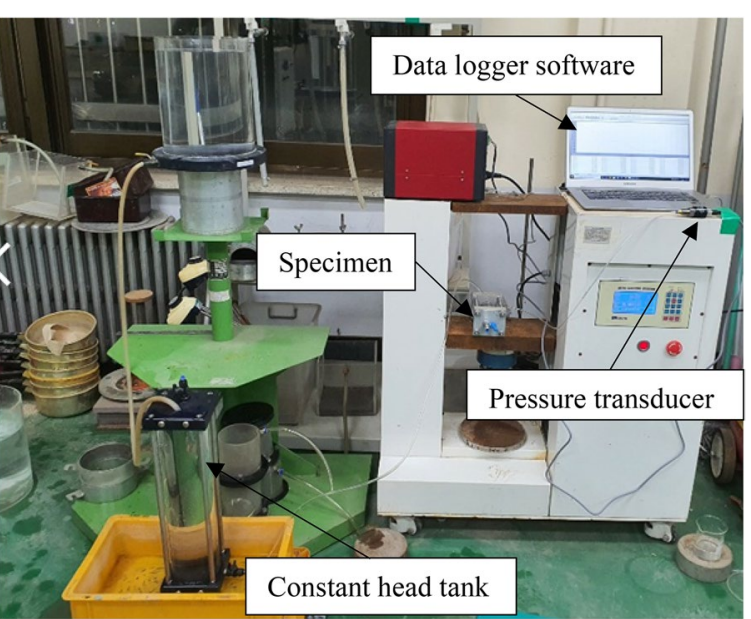

Fig. 6 Pinhole test set-up
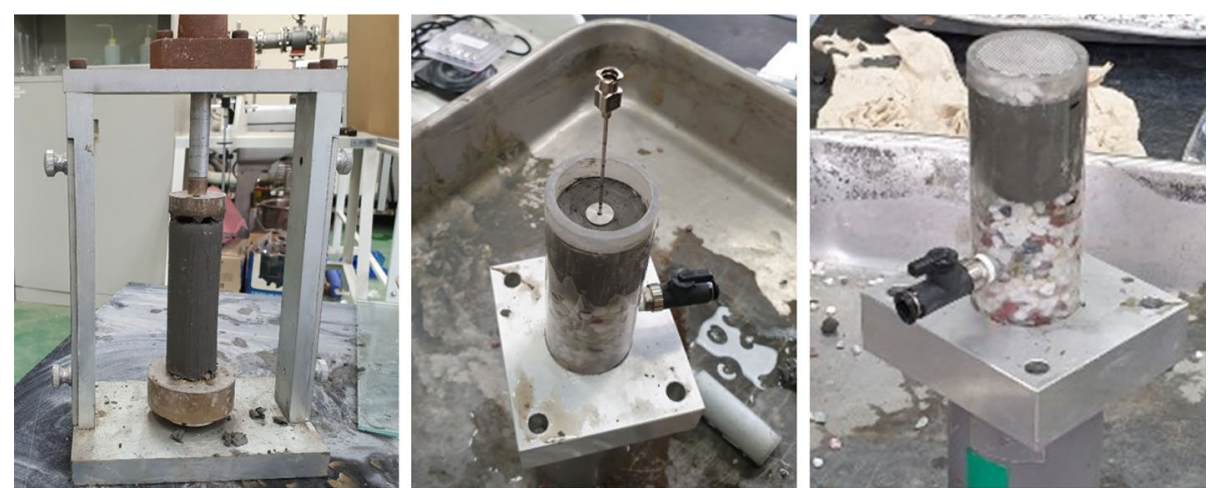

Fig. 7 Preparation of clay sample

and forced through the soil sample. Then, the wire screen was placed on top of the specimen and the remaining void in the top of the test cylinder was filled with coarse sand. Finally, the top plate was assembled, connected with the distilled water tank, and the pressure transducer (Fig. 6).

For clay, two samples were taken from different depths [RNB-23 (16.5 m) and RNB-23 $(18 \mathrm{~m})$ ], trimmed to a $38 \mathrm{~mm}$ long to fit snugly into the test cylinder. The test procedure for undisturbed samples is the same as that of disturbed samples (Fig. 7). It should be noted that the perimeter of the top of the clay sample was sealed with moulding clay to avoid the leach of water between the soil sample and the wall of the test cylinder. Besides, for some stiff clay samples, the penetration of the truncated cone guide nipple may be very difficult and results in the damage of the sample. Accordingly, the truncated cone guide nipple should be omitted in this case.

\section{Experimental procedure}

The experimental procedure is shown in Fig. 8. To measure the flow rate of the discharge, the outlet water was collected at an interval of $60 \mathrm{~s}$. Note that if there is no outlet 


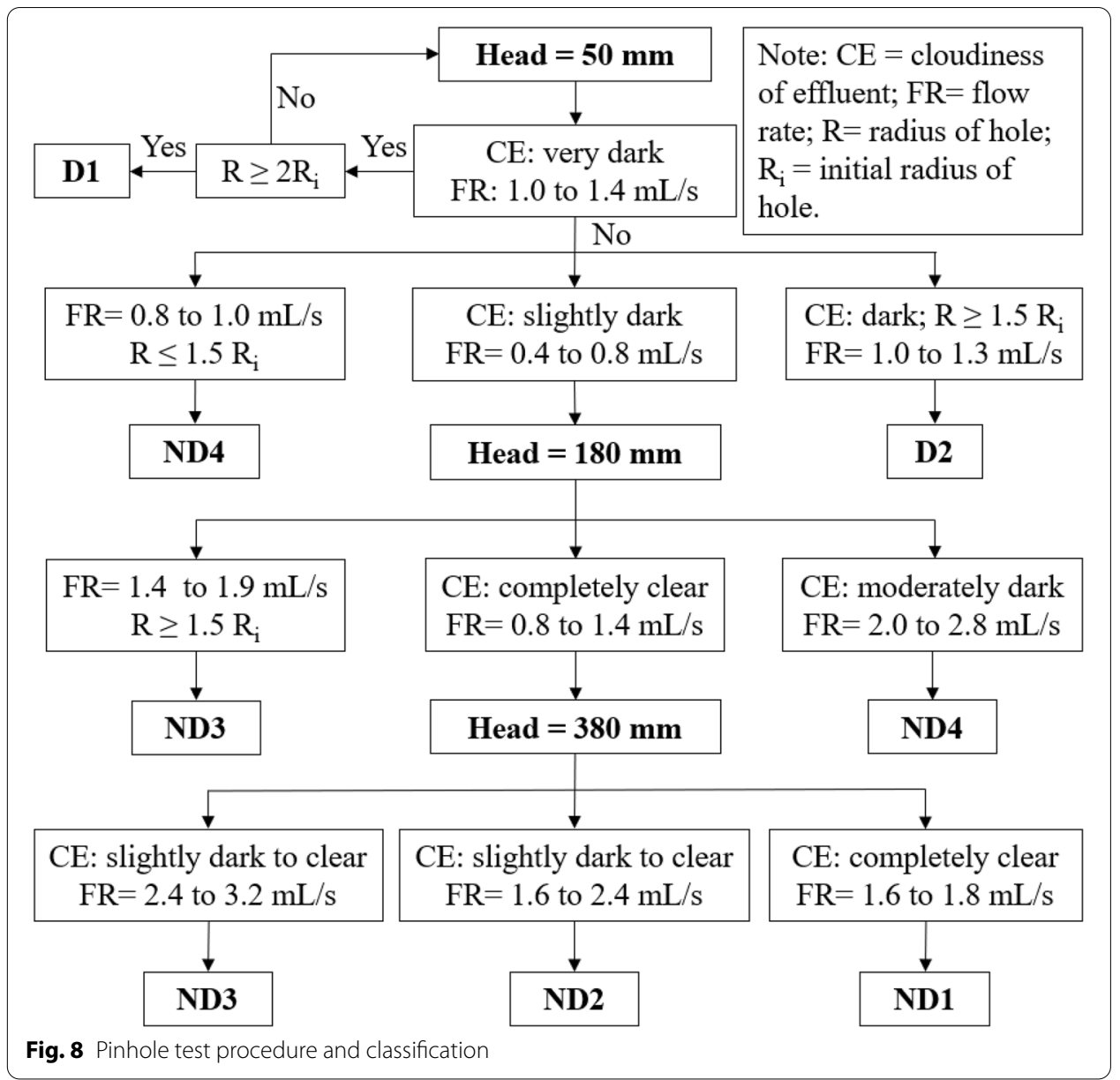

water at the start, the test should be stopped and then re-puncture the hole on the specimen. The cloudiness of the effluent, the flow rate, and the hole sizes are recorded as dispersive classification parameters. Based on these parameters, the soil can be classified as nondispersive (ND1 and ND2), slightly to moderately dispersive (ND3), moderately dispersive (ND4), dispersive (D2), and highly dispersive (D1) (Fig. 8).

\section{Results}

\section{Group 1: clay}

Figure 9 shows the flow rate and dispersive grade of clay samples (RNB-23 (16.5 m) and RNB-23 (18 m)). The hole size of the samples increased from 1.2 at the initial to $2.2 \mathrm{~mm}$ at the final stage of the test under the final applied head pressure of $380 \mathrm{~mm}$. However, the water collected from the test is completely clear (Fig. 10). Based on the results, the clay samples are classified as slightly to moderately dispersive soil and slow erosion (ND3).

\section{Group 2: SP-SM soil (RNB-2 and RNB-3)}

The testing results of group 2 soils are presented in Fig. 11. Under the head of $50 \mathrm{~mm}$, the final flow rate through the specimen is $1.33 \mathrm{~mL} / \mathrm{s}$ after the testing time of $5 \mathrm{~min}$. 


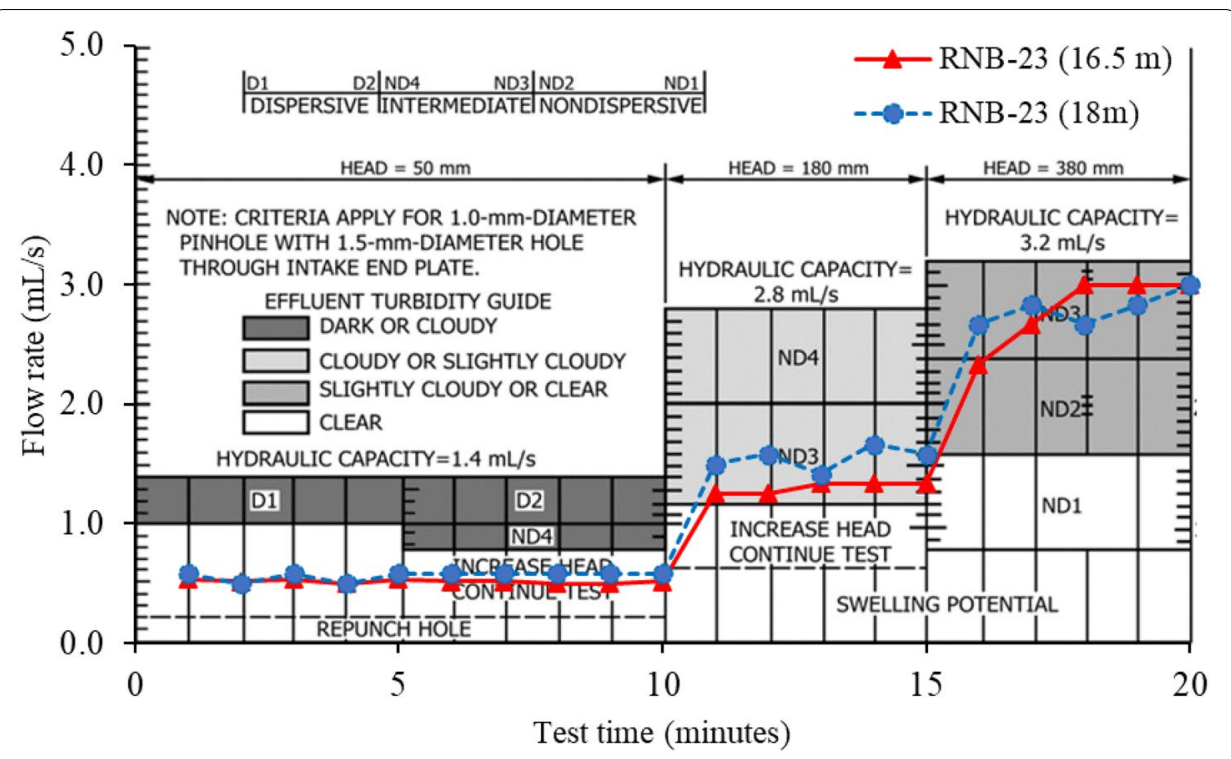

Fig. 9 Flow rate and dispersive grade of clay

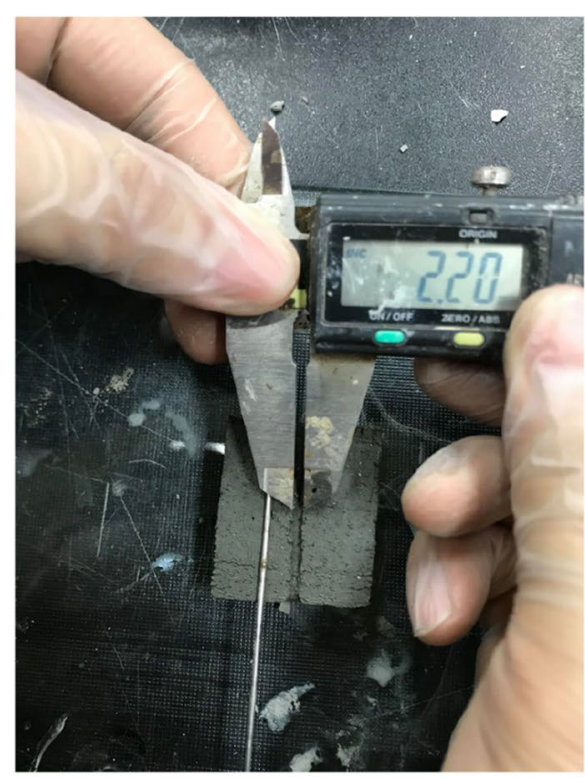

a

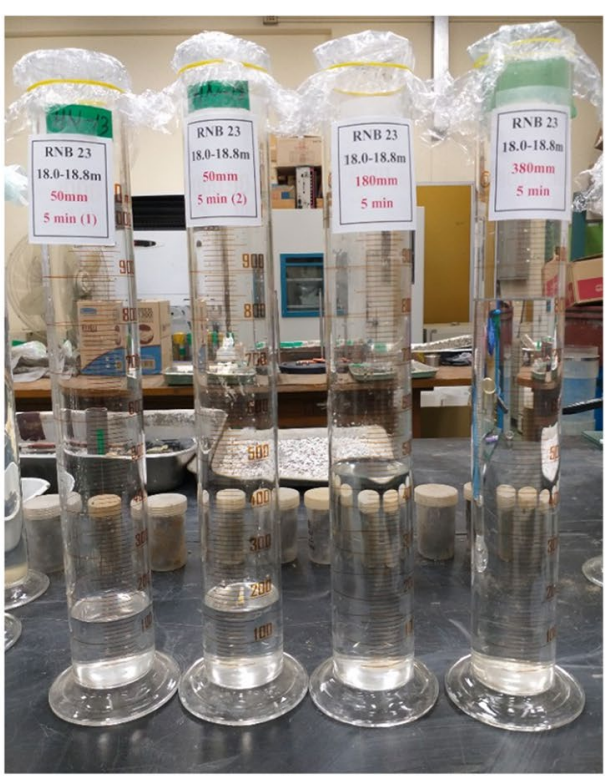

b

Fig. 10 a Hole size after test and $\mathbf{b}$ water collected from test

The diameters of the hole after the test were $3.73 \mathrm{~mm}$ (RNB-2) and $3.33 \mathrm{~mm}$ (RNB3 ), which is approximately three times larger than those of the initial hole diameter $(1.2 \mathrm{~mm})$. Furthermore, the water collected from the test is very dark from the side and top of the cylinder (Fig. 12). As a result, RNB-2 and RNB-3 are classified as highly dispersive soil and rapid erosion (D1). 


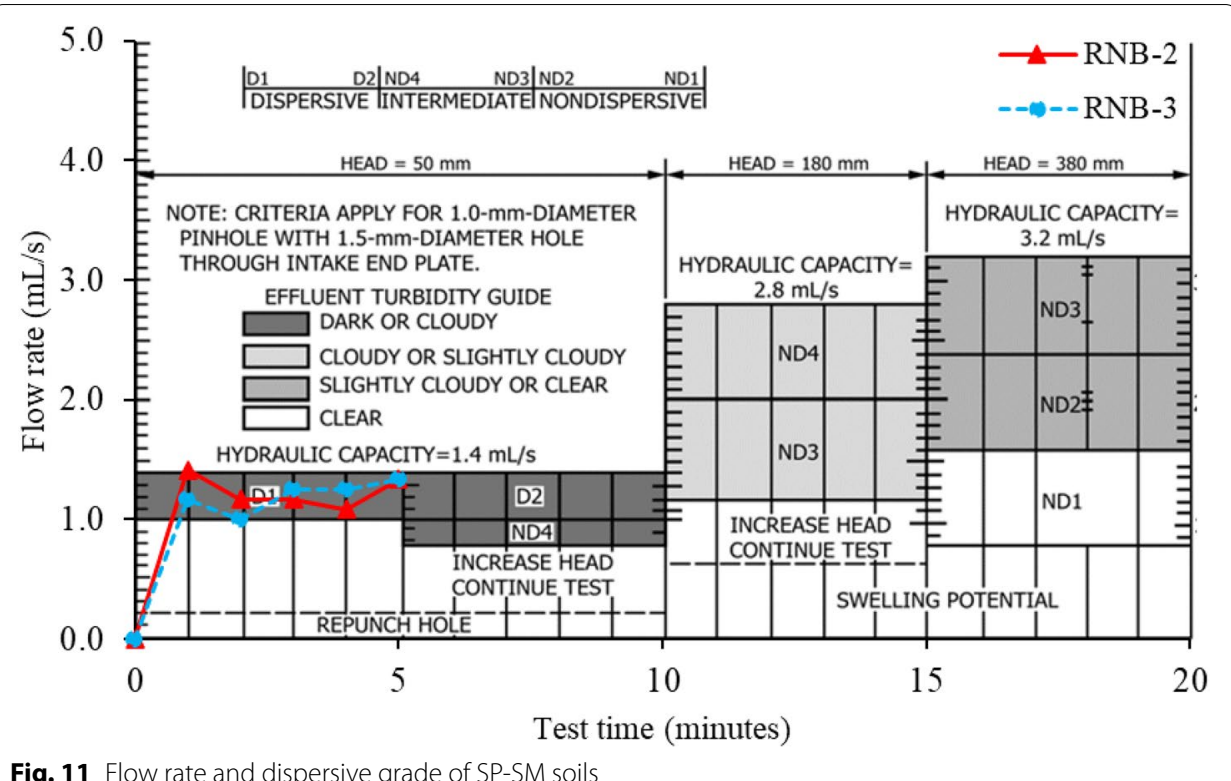

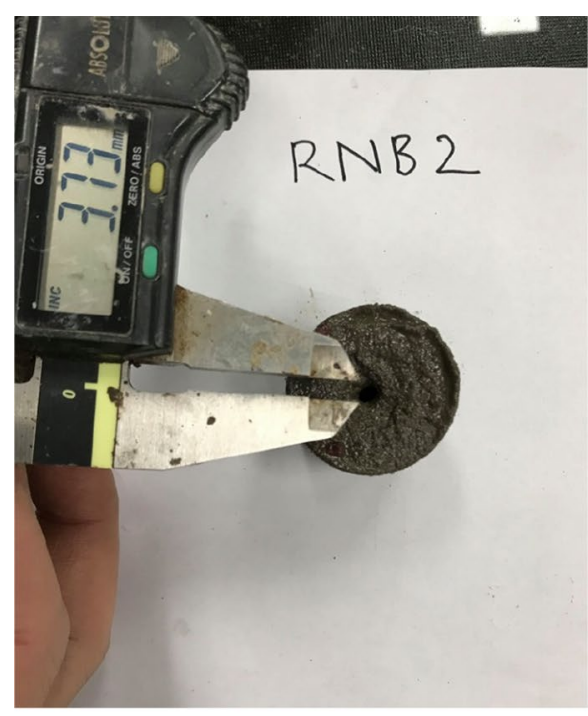

a

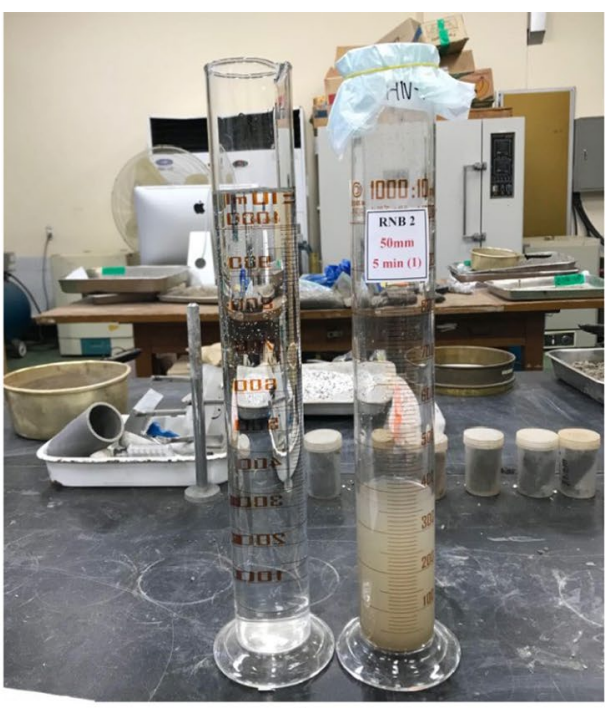

b

Fig. 12 a Hole size after test and $\mathbf{b}$ water collected from the test of SP-SM soils

\section{Group 3: SM soil (RNB-10, RNB-11, and RNB-13)}

The flow rate and dispersive grade of group 3 soils (RNB-10, RNB-11, RNB-13) are presented in Fig. 13. After $10 \mathrm{~min}$ under the head of $50 \mathrm{~mm}$, the final flow rate through the specimens ranged from 1.17 to $1.25 \mathrm{~mL} / \mathrm{s}$. The hole size after the test varies from 2.40 to $2.56 \mathrm{~mm}$, which is slightly smaller than that of group 2 soils (SP-SM). The flow at the end of the test from side and top is dark (Fig. 14). Thus, the SM soils are classified as rapid erosion soil. Since both the final flow rate and hole size after 


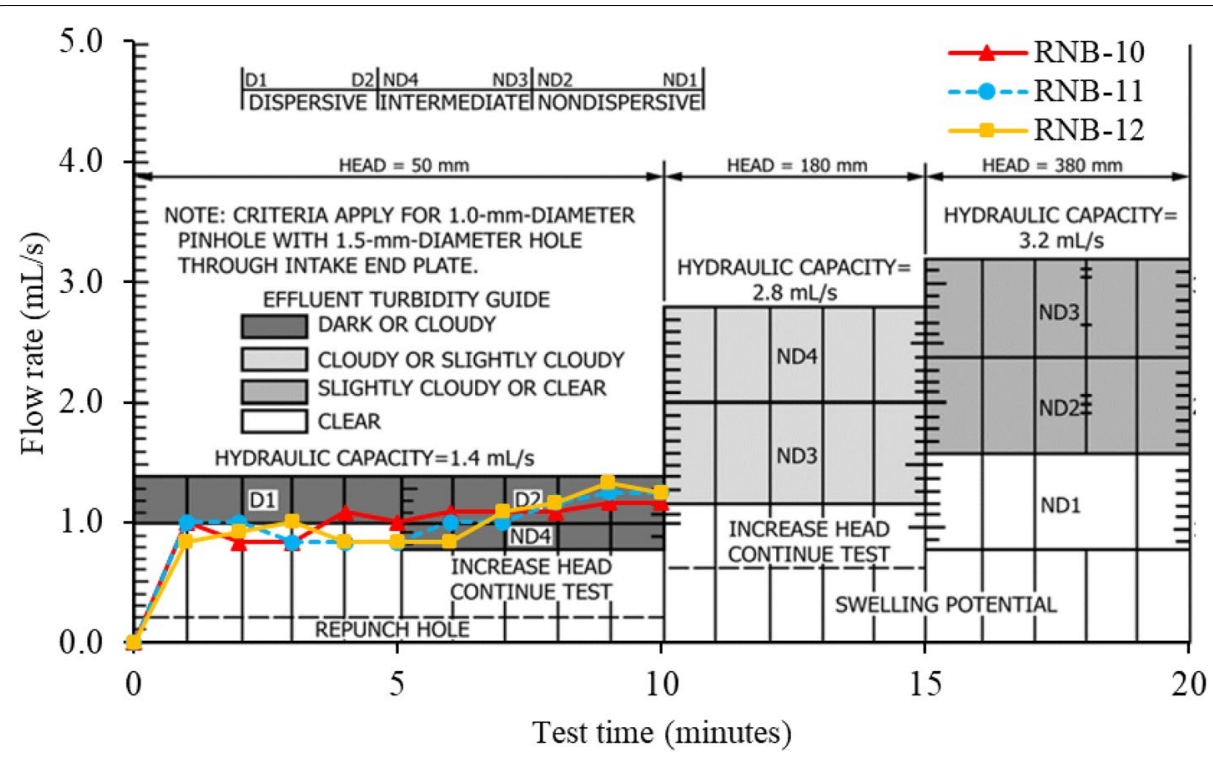

Fig. 13 Flow rate and dispersive grade of SP-SM soils

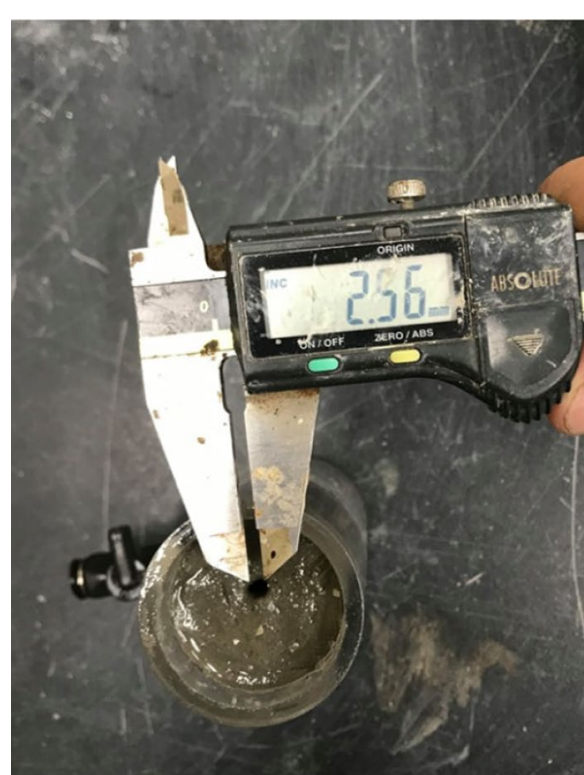

a

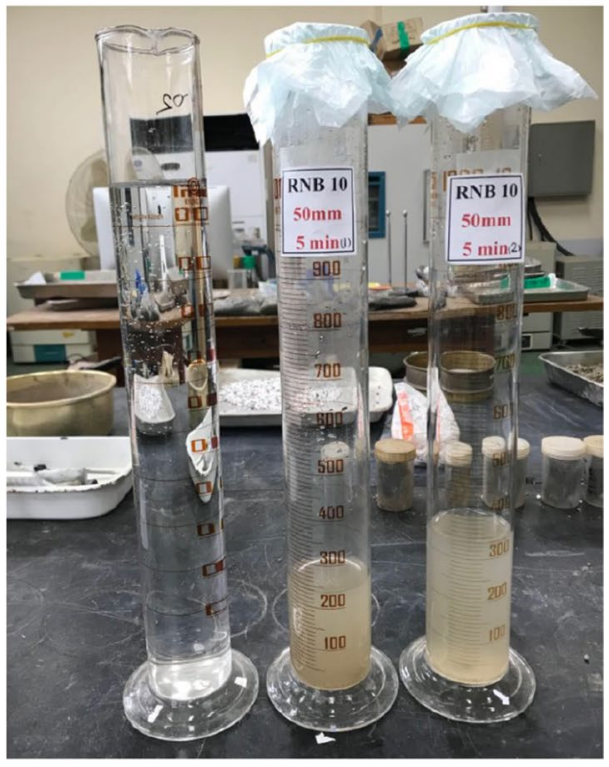

b

Fig. 14 a Hole size after test and $\mathbf{b}$ water collected from test

the test of group 3 size is lower than that of group 2 soils; therefore, as presented in Fig. 13, the group 3 soils (SM soils) is classified as dispersive soil (D2).

\section{Discussion}

\section{Effect of grain size distribution on the erosion of the soils}

Regarding the aforementioned results, SP-SM soils (RNB-2 and RNB-3) have the highest erosion level among three soil types. It is probably due to the fact that RNB-2 and RNB-3 
have a low percent of the small particle size between 7.4 and 7.0\% (Passing No. 200) respectively (Table 1). Furthermore, RNB-2 and RNB-3 curves are too uniform, i.e., $C_{u}<2$. According to Holtz and Kovacs (2011), very poorly graded soils have a $C_{u}$ of 2 or 3 such as beach sands, whereas very well graded soils may have $C_{u}$ of 15 or greater [11]. Thus, the void between the large particles is not filled with small particles as shown in Fig. 15 [26]. Therefore, RNB-2 and RNB-3 are more susceptible to erosion based on the piping failure mechanism [13]. The erosion result of SP-SM soils also agreed very well with the backward erosion piping mechanism presented in previous studies $[9,22,25]$. The backward erosion initially progresses in small channels rather than a single large channel. They found that poor grade soils with low uniformity coefficients $\left(C_{u}<3\right)$ are subject to backward erosion piping $[9,22,25]$. In this case, the large void between uniform soil particles may consider as small channels, where the small soil particles are transported at the initial process of backward erosion piping.

The frequency of each soil grain size is shown in Fig. 16. It is interesting to note that the grain size with the highest frequency of the rapid erosion soils (SM and SP-SM) ranged between 0.2 and $0.6 \mathrm{~mm}$, while the slow erosion soil (CL clays) has the highest frequency of grain size ranging from 0.05 to $0.09 \mathrm{~mm}$. Clearly, particles ranging between 0.2 and $0.6 \mathrm{~mm}$ of SP-SM soils (D1 class) are significantly larger than those of SM soils (D2 class). It is found that the grain size of $0.2-0.6 \mathrm{~mm}$ range is the most susceptible to soil erosion. The result of this study is in good agreement with the previous study [27].

\section{Analysis of the critical shear stress of soils from the pinhole test data}

The pinhole test uses the flow rate, diameter of the hole, cloudiness of the effluent, and applied pressure head to evaluate the erodilility of the soil. In this study, a process to analyze the erosion rate of soils by calculating the critical shear stress of soils from the pinhole test data is proposed. The empirical erosion law can be expressed as follows [5, 6, 24]:

$$
\dot{\varepsilon}=k_{e r}\left(\tau-\tau_{c}\right)
$$

where $\dot{\varepsilon}=$ erosion rate $\left(\mathrm{kg} \mathrm{m}^{-2} \mathrm{~s}^{-1}\right), \tau=$ shear stress $(\mathrm{Pa}), \tau_{c}=$ critical shear stress, and $k_{e r}=$ erosion coefficient.

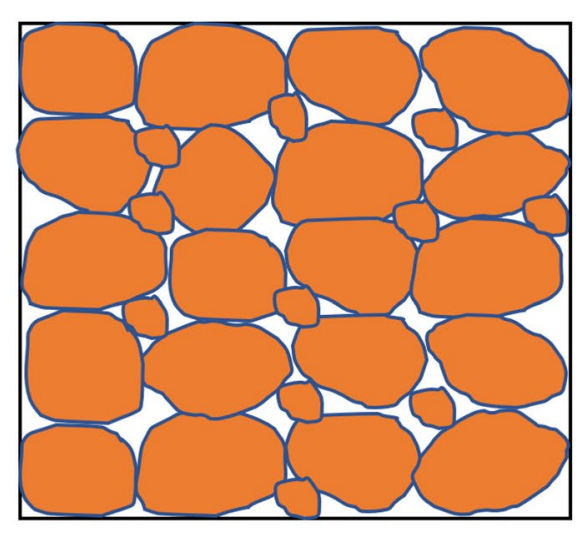

a

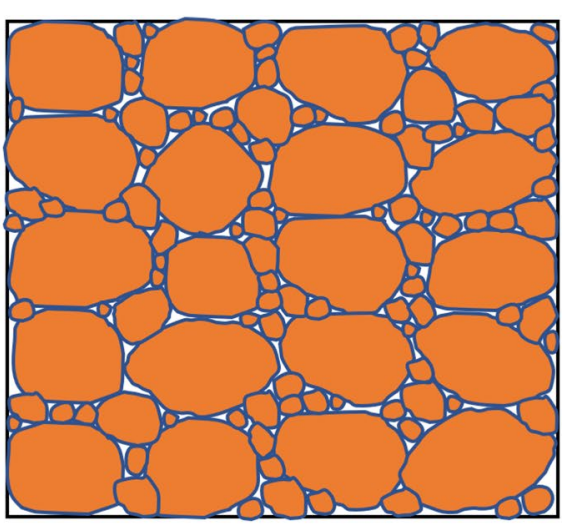

b

Fig. 15 Packing structures of a poorly graded soil (low $C_{u}$ ) and $\mathbf{b}$ well-graded soil (high $C_{u}$ ) 


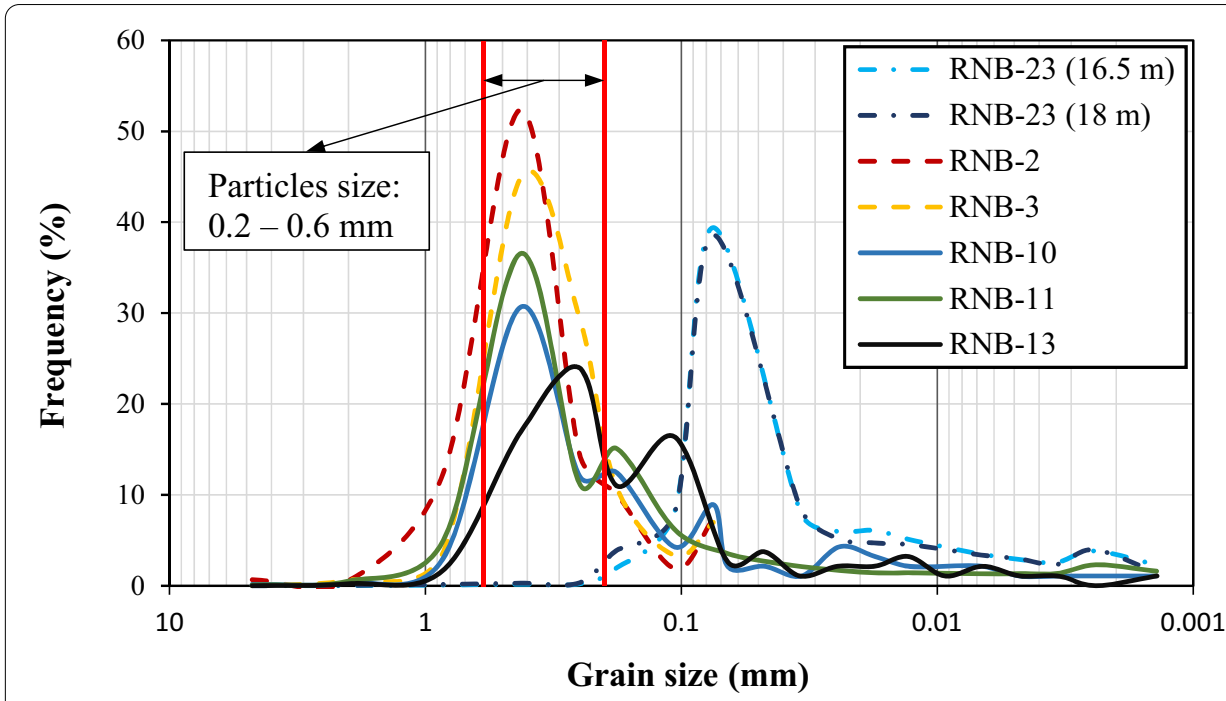

Fig. 16 Frequency of each grain size

Firstly, the shear stress in Eq. (1) can be calculated from the force equilibrium equation as follows:

$$
2 \pi r L \tau=\pi r^{2} \Delta P
$$

From Eq. (2), the shear stress $\tau$ can be calculated as follows:

$$
\tau=-\nabla P \frac{r(t)}{2}
$$

where: $L$ is the length of specimen $(0.038 \mathrm{~m}), \Delta P$ is head pressure $(0.05 \mathrm{~m}, 0.18 \mathrm{~m}$, or $0.38 \mathrm{~m})$; thus, $\nabla P=-\Delta P / L$ is the applied pressure gradient in the direction of the flow, $r(t)(\mathrm{m})$ is the hole size corresponding to the time $t$, and it can be calculated as follow [3-5]:

$$
r(t)=r_{i}\left(\frac{Q_{t}}{Q_{i}}\right)^{\frac{2}{5}}
$$

where: $r_{i}(\mathrm{~mm})$ is the initial hole size corresponding to the initial flow rate $Q_{i}\left(\mathrm{~m}^{3} / \mathrm{s}\right), Q(t)$ $\left(\mathrm{m}^{3} / \mathrm{s}\right)$ is the flow rate corresponding to the time $\mathrm{t}$.

Secondly, the erosion rate $\dot{\varepsilon}(t)$ in Eq. (1) is calculated as follows:

$$
\dot{\varepsilon}(t)=\frac{M_{S o-e r}(t)}{A \times t}
$$

where,

$$
M_{S o-e r}(t)=\rho_{s} L \pi\left(r_{(t)}^{2}-r_{i}^{2}\right)
$$

where: $t=$ reference time (s), $M_{S o-e r}=$ mass of soil eroded at time $t(\mathrm{~kg}), r(t)=$ hole size corresponding to the time $\mathrm{t}(\mathrm{s}), r_{i}=$ initial hole size $(\mathrm{m})$. 


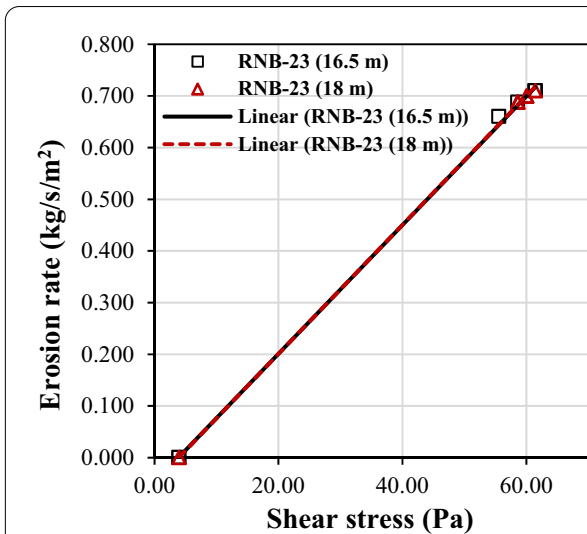

a

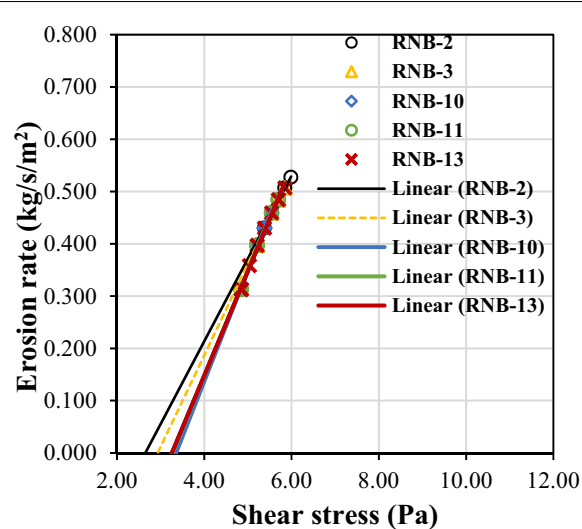

b

Fig. 17 Critical shear stress of $\mathbf{a}$ clay and $\mathbf{b}$ SM and SP-SM soils

Table 2 Dispersive classification and critical shear stress of soils

\begin{tabular}{llllll}
\hline Group & $\begin{array}{l}\text { Dispersive } \\
\text { classification }\end{array}$ & Name & $\begin{array}{l}\text { Erosion } \\
\text { coefficients }(\mathrm{s} / \mathrm{m})\end{array}$ & $\begin{array}{l}\text { Critical shear } \\
\text { stress }(\mathrm{Pa})\end{array}$ & Note $\tau_{c}(\mathrm{~Pa})$ \\
\hline 1 & ND3 & RNB-23 $(16.5 \mathrm{~m})$ & 0.013 & 3.86 & $>3.5$ \\
& & RNB-23 $(18 \mathrm{~m})$ & 0.012 & 3.80 & $<3.0$ \\
3 & RNB-2 & 0.158 & 2.65 & $3.0<\tau_{c}<3.5$ \\
& & RNB-3 & 0.175 & 2.93 & \\
& D2 & RNB-10 & 0.212 & 3.35 & \\
& & RNB-11 & 0.202 & 3.27 & \\
& & RNB-13 & 0.199 & 3.26 & \\
\hline
\end{tabular}

The critical shear stress analysis results from pinhole test data are shown in Fig. 17. The linear relationship between erosion rate and shear stress is observed regardless of soil types; thus, the proposed empirical erosion law (Eq. (1)) is reasonable for determining critical shear stress. The erosion coefficients and critical shear stress of soils calculated from proposed equations are presented in Table 2. The erosion coefficients of clay are approximately 13 times and 16 times smaller than those of the SM and SP-SM soils, respectively. Accordingly, the erosion coefficients can be used to distinguish between the low erosion (ND3 and ND4) and high erosion soils (D1 and D2). Besides, the lower dispersive class, the higher the critical shear stress is identified (Table 2). It can be carefully concluded that the critical shear stress might be used to classify the erosion of the soil such as $\tau_{c}>3.5 \mathrm{~Pa}$ (ND3), 3.0 $\mathrm{Pa}<\tau_{c}<3.5 \mathrm{~Pa}$ (D2), and $\tau_{c}<3.0 \mathrm{~Pa}$ (D1).

\section{Conclusions}

1. This paper evaluates the erosion of the soil using a pinhole test. The clay, SP-SM, and SM soil were classified as slightly to moderately dispersive soil (ND3), highly dispersive soil (D1), and dispersive soil (D2).

2. The particle size distribution and coefficient of uniformity of soils are significant factors that affect the erosion of the soil. The well-graded soil has a low erodibility com- 
pared to that of the poorly graded one. The soil with a grain size ranging from 0.2 to $0.6 \mathrm{~mm}$ is most susceptible to soil erosion.

3. The erosion coefficients and the critical shear stress were calculated from the results of pinhole test as an additional parameter for classifying the erosion of the soil. The erosion coefficient is feasible to use to identify between the low erosion (ND3 and ND4) and high erosion soils (D1 and D2). Meanwhile, the critical shear stress might be used as a classification parameter of erosion of the soil as: $\tau_{c}>3.5 \mathrm{~Pa}$ (ND3), 3.0 $\mathrm{Pa}<\tau_{c}<3.5 \mathrm{~Pa}(\mathrm{D} 2)$, and $\tau_{c}<3.0 \mathrm{~Pa}$ (D1). However, this result should be further studied.

\section{Authors' contributions}

BHD: Investigation, Methodology, Writing—original draft; A-DN: Investigation, Methodology; S-YJ: Methodology, Validation; Y-SK: Supervision, Validation, Writing-review and editing.

\section{Competing interests}

The authors declare that they have no competing interests.

\section{Author details}

${ }^{1}$ Department of Architecture and Civil Engineering, Chonnam National University, Yongbong-ro 77, Buk-gu, Gwangju 61186, South Korea. ${ }^{2}$ Department of Architecture Engineering, Chonnam National University, Yongbong-ro 77, Buk-gu, Gwangju 61186, South Korea. ${ }^{3}$ Department of Civil Engineering, Chonnam National University, Yongbong-ro 77 , Buk-gu, Gwangju 61186, South Korea.

Received: 20 November 2020 Accepted: 18 February 2021

Published online: 07 June 2021

\section{References}

1. Arulanandan K, Gillogley E, Tully R (1980) Development of a quantitative method to predict critical shear stress and rate of erosion of natural undisturbed cohesive soils. Technical rep. GL-80-5, U.S. Army Engineers, waterways experiment station, Vicksburg, MS

2. ASTM (2006) Standard test method for identification and classification of dispersive clay soils by the pinhole test. ASTM, West Conshohocken (D4647)

3. Benahmed N, Bonelli S (2007) Etude expérimentale de l'érosion interne d'une kaolinite. Proc., 25e rencontre de I'AUGC, Bordeaux, France (in French)

4. Bonelli S, Brivois O, Borghi R, Benahmed N (2006) On the modelling of piping erosion. C R Mécanique 334(8-9):555-559

5. Bonelli S, Brivois O (2008) The scaling law in the hole erosion test with a constant pressure drop. Int J Numer Anal Methods Geomech 32(13):1573-1595

6. Briaud JL, Ting FCK, Chen HC, Cao Y (2011) Erosion function apparatus for scour rate predictions. J Geotech Geoenviron Eng 127(2):105-113

7. Chevalier C, Haghighi I, Pham TL, Reiffsteck P (2010) Two complementary tests for characterizing the soil erosion. Proc, 5th Int Conf Scour Eros, ASCE, Reston, VA, 152-161

8. Emerson WW (1967) A classification of soil aggregates based on their coherence in water. Aust J Soil Res 5:47-57

9. Fell R, Fry JJ (2013) State of the art on the likelihood of internal erosion of dams and levees by means of testing. In: Bonelli S, Nicot F (eds) Erosion in geomechnics applied to dams and levees. Wiley, Hooboken

10. Hanson GJ, Cook KR (2004) Apparatus, test procedures, and analytical methods to measure soil erodibility in situ. Appl Eng Agric 20(4):455-462

11. Holtz RD, Kovacs WD (1981) An introduction to geotechnical engineering, 2nd edn. Prentice hall, Hoboken

12. Koreajoongangdaily (2014) https://koreajoongangdaily.joins.com/2014/08/27/socialAffairs/Sinkholes-are-here-tostay/2994167.html. Accessed 12 Nov 2020

13. Knodel PC (1991) Characteristics of dispersive and problems clay soils. Technical report, materials engineering branch, U.S. Department of the interior

14. Lee WF, Ishihara K (2011) Piping failure of a metro tunnel construction, proceeding of TC302 symposium Osaka: international symposium on backwards problem in geotechnical engineering and monitoring of geo-construction pp. 73-82

15. Olsen NRB, Haun S (2020) A numerical geotechnical model for computing soil slides at banks of water reservoirs. Int J Geo-Eng 11(22). https://doi.org/10.1186/s40703-020-00129-w

16. Pirouzi A, Eslami A (2017) Ground subsidence in plains around Tehran: site survey, records compilation and analysis. Int J Geo-Eng 8(30). https://doi.org/10.1186/s40703-017-0069-4 
17. Ramesh V, Mani S, Baskar M, Kavitha G, Anbazhagan S (2017) Landslide hazard zonation mapping and cut slope stability analyses along Yercaud ghat road (Kuppanur-Yercaud) section, Tamil Nadu, India. Int J Geo-Eng 8(2). https:// doi.org/10.1186/s40703-017-0039-x

18. Reddi LN, Lee I, Bonala MVS (2000) Comparison of internal and surface erosion using flow pump test on a sandkaolin mixture. Geotech Test J 23(1):116-122

19. Reiffsteck P (2007) Evaluation of erosion of soil used in dykes and earth embankments which are subjected to flood. Workshop Int Eros Piping Dams Found, Lavoisier, Aussois, France, 191-202

20. Sherard JL, Dunnigan LP, Decker RS, Steele EF (1976) Pinhole test for identifying dispersive soils. J Geotech Eng Div ASCE 102(GT1):69-85

21. Sherard JL, Dunnigan LP, Decker RS (1976) Identification and nature of dispersive soils. J Geotech Eng Div ASCE 102(GT4):287-301

22. Silvis F (1991) Verificatie piping model; Proeven in de Deltagoot. Evaluatierapport. Rapport Grondmechanica Delft, $\mathrm{CO} 317710 / 7$

23. Talukdar P, Dey A (2019) Hydraulic failures of earthen dams and embankments. Innov Infrastruct Solut. https://doi. org/10.1007/s41062-019-0229-9

24. Wan CF, Fell R (2004) Investigation of rate of erosion of soils in embankment dams. J Geotech Geoenviron Eng 130(4):373-380

25. Weijers JBA, Sellmeijer JB (1993) A new model to deal with the piping mechanism. In: Brauns J, Herbaum M, Schuler $\cup$ (eds) Filters in geotechnical and hydraulic engineering. Balkema, Rotterdam

26. Xu Z, Xu N, Wang H (2019) Effects of particle shapes and sizes on the minimum void ratios of sand. Adv Civ Eng 2019:1-12. https://doi.org/10.1155/2019/5732656

27. Zhao P, Shao MA, Omran W, Amer AM (2011) Effects of erosion and deposition on particle size distribution of deposited farmland soils on the Chinese loess plateau. Rev Bras Ciênc Solo 35(6):2135-2144. https://doi.org/10.1590/ s0100-06832011000600028

\section{Publisher's Note}

Springer Nature remains neutral with regard to jurisdictional claims in published maps and institutional affiliations.

\section{Submit your manuscript to a SpringerOpen ${ }^{\circ}$ journal and benefit from:}

- Convenient online submission

- Rigorous peer review

- Open access: articles freely available online

- High visibility within the field

- Retaining the copyright to your article

Submit your next manuscript at $\boldsymbol{\nabla}$ springeropen.com 